\title{
The politics of the excluded: abjection and reconciliation amongst the British precariat
}

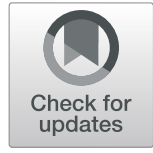

\author{
Mike Savage ${ }^{1 *}$ and Cynthia Meersohn Schmidt ${ }^{2}$
}

\footnotetext{
* Correspondence: M.A.Savage@lse. ac.uk

${ }^{1}$ London School of Economics and Political Science, London, UK Full list of author information is available at the end of the article
}

\begin{abstract}
In this paper, we use a powerful empirical resource to address what the popular politics of disadvantage might entail in contemporary Britain. We take advantage of the unusually rich qualitative data from the British National Child Development Study, a cohort of Britons born in 1 week in 1958, to focus specifically on the accounts of those who are particularly disadvantaged. By concentrating on these a small number of qualitative accounts, which have been rigorously selected from the wider nationally representative sample on the basis of their relatively small amounts of economic and cultural capital, we will explore in detail the accounts and identities of these disadvantaged Britons with a view to explicating their political frameworks, their social identities and more broadly their orientations towards mobilisation.
\end{abstract}

Keywords: Class, Politics of disadvantage, Britain

\section{Introduction}

The mushrooming of social inequality and the rise of new class inequalities in recent decades have posed major challenges for understanding the dynamics of contemporary political mobilisation and contestation. There is growing evidence for the formation of an increasingly distinctive and powerful corporate, propertied and wealthy elite (Stiglitz 2011; Piketty 2014; Dorling 2014; Atkinson et al. 2011; Atkinson 2015; Savage et al. 2015). This relatively small group has dramatically advanced its fortunes leading to an escalating gap between the rich and the poor. At the lower end of the social structure, there is growing evidence of the persistence and indeed growth of a precarious and insecure group, socially marginalised and dependent on insecure labour markets, affected by casualization and by the erosion of welfare payments (see e.g. Standing 2011; Lansey and Mack 2015; Hills 2014; McKenzie 2015).

Yet, the emerging politics of class conflict within these enhanced inequalities remains unclear. Calhoun (2015) has argued that the 2008 financial crash has been the first crisis in the history of capitalism which has not generated a strong political response from radical, socialist and anti-establishment forces. As underscored by the rise of populist politics amongst the disadvantaged in many parts of the world, there is little evidence for the overt radicalisation or class consciousness (on the UK see e.g. Shildrick and Macdonald 2013; Shildrick et al. 2013; McKenzie 2015; Evans and Tilley 2017). There

(c) The Author(s). 2020 Open Access This article is licensed under a Creative Commons Attribution 4.0 International License, which permits use, sharing, adaptation, distribution and reproduction in any medium or format, as long as you give appropriate credit to the original author(s) and the source, provide a link to the Creative Commons licence, and indicate if changes were made. The images or other third party material in this article are included in the article's Creative Commons licence, unless indicated otherwise in a credit line to the material. If material is not included in the article's Creative Commons licence and your intended use is not permitted by statutory regulation or exceeds the permitted use, you will need to obtain permission directly from the copyright holder. To view a copy of this licence, visit http://creativecommons.org/licenses/by/4.0/. 
has certainly been large scale disenchantment from orthodox political parties and organisations, but in recent years, this has rarely been translated into outright opposition or resistance in the most advanced capitalist nations, though it has in certain cases taken populist, xenophobic and anti-establishment lines (see Flemmen and Savage 2017).

Savage articulates the "paradox of class", whereby intensifying economic class inequalities seems to be associated with decreasing overt political class consciousness, limited political mobilisation on class lines and more ambivalent class identities (Savage 2000; Savage et al. 2001; Skeggs 2004; Savage et al 2010; Savage et al. 2015). In this paper, we use an original empirical resource to address the popular politics of disadvantage might entail in contemporary Britain. We take advantage of the unusually rich qualitative data from the British National Child Development Study, a cohort of Britons born in 1 week in 1958, to focus specifically on the accounts of those who are particularly disadvantaged. By concentrating on a small number of qualitative accounts, which have been rigorously selected from the wider nationally representative sample on the basis of their relatively small amounts of economic and cultural capital, we will explore in detail the accounts and identities of these disadvantaged Britons with a view to explicating their political frameworks, their social identities and more broadly their orientations towards mobilisation.

The British case is especially interesting in comparative perspective for two reasons. Firstly, it is a nation where there has been an unusually rapid growth of inequality in recent decades. Having been characterised by relatively redistributionist politics up till the early 1980s, its levels of inequality (e.g. as measured by the Gini coefficient) are now amongst the highest in Europe (see e.g. Savage et al. 2015; Piketty 2014; Hills 2014; Alvaredo et al. 2017). This is associated with its highly unbalanced economy in which its global centrality in financial and corporate networks goes hand in hand with the weakness of its manufacturing base. Secondly, it is also a nation with a very strong historical tradition of popular mobilisation, most clearly exemplified through the central role of the labour movement in its political and social fabric. Historians such as McKibbin (1998) see the presence of the labour movement as the defining feature of British society in the mid-twentieth century, to such an extent that the middle and upper classes had to define themselves in opposition to it. However, by the early twenty-first century, the labour movement had lost its vitality, with trade union membership halving between the later 1970s and the early twenty-first century, and the labour party distancing itself from its socialist politics. The scale and speed of this transformation in Britain makes it a particularly important comparative case.

We begin by reviewing the key theoretical frameworks which seek to explain the limitations of working class political action. We compare the accounts of those pointing to structural and institutional political difficulties in mobilising those at the bottom of the social hierarchy with Bourdieusian framings stressing the role of "mis-recognition" (notably Skeggs 1997, see also Savage et al. 2001) and suffering and domination (Bourdieu et al 1999; Atkinson et al. 2011). We also review the recent deployment of feminist concepts of "abjection" and "stigma" (Tyler 2014; 2020) which place these concerns amidst an engagement with personal, embodied, narratives.

In the second section, we introduce the NCDS data, rehearsing the unusual strengths which it brings for isolating a sample drawn from the most disadvantaged positions. The third section of the paper examines evidence for overt political identification and 
class awareness amongst disadvantaged Britons. The interviews show that most of the respondents have a clear view about their disadvantaged class position and recognise their subordinate social positioning at the bottom of the British social structure.

The fourth section considers more directly issues of personal abjection, shame and stigma, reporting our coding of the interviews from respondents. We show how a key feature of many of our interviewee's accounts is dealing with personal difficulty, sometimes amounting to trauma, often associated with health problems or abusive personal relationships. We argue that we need to take serious account of these personal narratives in understanding the accounts and world views of respondents, and we should not simply see them as a cipher of some overarching variable.

\section{Prospects for "poor people's politics" in the twenty-first century}

There are currently four families of explanation for addressing the significance of popular and working class politics amongst those located in the most disadvantaged social locations: (i) arguments about political leadership and organisation, (ii) Bourdieusian claims about mis-recognition and dis-identification, (iii) the individualisation of risk biographies, (iv) more recent theorisations of abjection and stigma.

\section{The limits of working class leadership}

The most immediate explanation of the limited working class political engagement focuses on the inherent problems entailed in the institutional leadership of popular movements. Such perspectives are varied, but generally point to the intrinsic difficulties in mobilising subordinate social groups. They have theoretical warrant in the thinking of both Marx and (especially) Weber who draw attention to the lack of interplay between "class-in-itself" and "class-for-itself" or economic and social class (see e.g. Scott 1996). They can be associated with Lenin's famous argument that the working class tends towards "trade union" consciousness unless led by a revolutionary party, or Bourdieu's emphasis on the "culture of necessity" which characterises those without economic, cultural and social capital. In this vein, Wacquant (2001) has insisted that those in dominated positions are not heroic or radical figures but are defined by their deprivation and marginality to the extent that they become complicit in their own marginality.

These perspectives have recently been recharged by the rise of analytical sociology, including rational action theory, which characteristically points to the problems of collective action (as in the "prisoner's dilemma"). A highly influential perspective is that by Offe and Wisenthal (1980) which contrasts the inherent atomism of labour, necessarily embedded in the individual bodies of workers, with that of capital, which can be accumulated and hence mobilised more readily by its owners. One extension of this argument, for instance by Calhoun (1982), is to see collective action by those in subordinate positions as dependent on external collective or community organisation which is generated externally to capitalist relations themselves, which is hence liable to be only contingently available as resources for mobilisation. In the context of possibly declining communal and neighbourhood solidarities (as extensively discussed in the debate inspired by Putnam 2000), this might entail the poor in advanced capitalist society becoming increasingly atomised and difficult to mobilise. 
A related argument initiated by Przeworski in Capitalism and Democracy (Przeworski 1985) emphasises the dilemmas of socialist parties when they pursue democratic, votewinning strategies. As the proportion of the manual working class declines within the class structures of advanced capitalism, the stakes for political parties and movements to appeal to this disadvantaged working class bloc reduces. Whereas there is considerable rationality in appealing to the dispossessed where substantial proportions, indeed majorities, of the electorate are in such positions, there is less strategic value in mobilising on these grounds when larger proportions of the electorate become more affluent. In these circumstances, political parties and institutions of all kinds default towards appealing to the "middle ground". These arguments seem amply borne out by the trajectory of both the Labour Party and the Conservative Party since the mid-1990s as they moved towards the political centre ground (Evans and Tilley 2012; Evans and Tilley 2017; Piketty 2014).

Whilst such institutionalist perspectives are useful, it is doubtful that they adequately explain contemporary popular political repertoires in an era of growing inequality. In fact, given the extremes of wealth inequality which increasingly mark contemporary capitalism, it should be instrumentally rational for socialist or left-leaning political parties to propose taxing the small number of very wealthy as a means of allowing either tax cuts or enhanced public spending to benefit the majority of the electorate. One might rationally argue that a hefty income or wealth tax on the top $1 \%$ would alienate very few voters and would deliver tangible benefits to the great majority. However, the fact that where such proposals to introduce redistributionist politics-for instance by the Labour Party in the 2015 election-have had only limited success indicates that there are more than purely institutional and political strategic reasons for the weakness of popular politics.

\section{Class misrecognition}

The second perspective, affiliated with Bourdieusian currents, emphasises the routine and profound "mis-recognition" of social relationships and focuses on the "dis-identification" from class which this generates. For Bourdieu, the mis-recognition of social relationships is fundamental and systematic. This involves the "naturalising" of socially constructed processes, for instance along the lines of Marx's analysis of "commodity fetishism", so that women might be seen as "naturally" less high-achieving than men or poor people "naturally" less talented than the middle classes. An important version of this argument has been famously articulated by Skeggs (1997) in her account of the "class dis-identification" of disadvantaged young working class women in the English midlands in the 1980s. Skeggs argues that rather than social marginalisation leading to class conscious awareness of their deprivation, these young women instead vested in "respectable" and "feminine" identities, which hence disavowed more radical political repertoires.

This highly influential argument chimes with the considerable evidence for ambivalent, defensive and political class identities which are often detected in contemporary capitalism (e.g. Charlesworth 2000; Savage et al. 2001; 2010). In their analysis of the Great British Class Survey, Savage et al. (2015) show that overt class identities decline amongst those who are most disadvantaged. In his celebrated Weight of the World, 
Bourdieu argues that those who are most marginalised experience their lives as shameful and as oriented around "suffering"-which can be seen as a naturalisation of their own location in stigmatised and dominated positions. This argument has been pursued in related fashion by Atkinson (Atkinson et al. 2011), who, drawing on qualitative interviews with respondents in the UK, has drawn attention to the "dominated" characteristics of those without cultural and economic capital.

We see this focus on the experience of "suffering" as more powerful than that of "misrecognition", which can be seen as a partial reworking of the "dominant ideology thesis" which originates with Marx. As with all forms of "dominant ideology thesis", there is a danger that researchers can read behind the overt accounts of respondents as mis-recognition of their actual situation (as decided by the researchers). There is a danger therefore in not being sensitive to the meanings and accounts provided by the participants themselves. Here, Martin's (2011) insistence that we take people's own words and accounts seriously is of fundamental importance. In fact, the poor and disadvantaged are frequently aware of their own position and do not obviously dis-identify. Lisa McKenzie's ethnography of St. Ann's in Nottingham emphasises that “( $t)$ he white working-class women on this estate know that they are thought of as "rough and ready", they understand this through what is known, and thought, about them; the way they act, where they live and who they share their beds with adds to this stigmatisation" (Mckenzie 2015: 69). This leads us to suggest that there is a useful congruence between this Bourdieusian perspective and sociological theories of individualisation.

\section{Individualisation}

The third perspective explores how individual disadvantages are managed against growing global inequalities. Beck and Beck-Gernsheim (2002) argue that the institutional shift towards individuals has eroded traditional collective ties such as family, neighbourhood, occupation and class. These ties have been replaced with what they call a culture of freedom. The culture of freedom gears individuals towards shaping their biographies in their own terms, independent from traditional ties, and supported by institutional arrangements offering alternatives to creating a "life of their own" as long as they are willing to be economically active. This shift from lives organised around local traditional institutions to lives organised by personal projects is individualisation.

Despite flexible lifestyles afforded by individualisation processes, they also come at the cost of increased pressure on individuals to manage the risks associated with their chosen biographical paths. Weakened traditional institutions are unable to mitigate the increased vulnerability of individuals to the fluctuations of the labour market. Although these risks are partially offset by social protection, increasing global inequalities highlight the precariousness of individualisation processes, especially amongst disadvantaged groups which are at a greater risk of suffering severe disruptions to their biographies.

The growing number of individuals living precarious lives poses a problem for identification, and particularly for class identity. No longer rooted in traditional identities, and not taking secure steps towards fulfilment of personal projects, individuals remain uncertain of their position in society. Beck and Beck-Gernsheim's (2002: 36) interpretation is that "the waning of traditional lifestyles, does not bring the end of class, but 
rather emancipates classes from regional and particularist limitations". Identity now rests on contingently formed ties during individual biographies. Class is thus reliant on the shared experiences of individuals striving to fulfil their life projects. The notion of identity finding footing in successful attempts to "switch on" to unstable institutional arrangements has been more broadly developed by White (2008). Individualisation processes are efforts to dress an inherently unstable society under a cover of certainty. Individual quests for fulfilment comprise self-enlightenment and self-improvement endeavours, by which individuals internalise and absorb the risk and responsibility associated with precarious lifestyles.

However, Beck and Beck-Gernsheim warn that the internalisation of risks in not limitless. Repeated frustration over access to self-improvement opportunities or over the futility of invested efforts may shift individual perceptions from a "risk biography" to a "danger biography", in which individuals recognise their marginalisation by lack of control over the direction of their biographies, rather than identifying with a particular social class.

\section{Abjection and stigma}

The fourth perspective elaborates on accounts of "abjection", notably as developed recently by Tyler (2014), who draws on Julia Kristeva. To some extent, this argument builds on Foucault's interest in the "productivity" of power in neoliberal conditions, in which subjects take on and articulate the discourses by which they are identified, classified and governed by. Tyler's arguments about "social abjection" focus on "the violent exclusionary forces of sovereign power; those forces that strip people of their human dignity and reproduce them as dehumanised waste, the disposable dregs and refuse of social life" (Tyler 2014: 21). Tyler argues that abjection is a mode of governance-"a mechanism of governance through aversion"-and operates through producing forms of disgust, which lead to repulsion, yet they also necessarily form the terrain on which those subject to "abjection" mobilise and identify. Abjection is thereby recognised by participants and becomes the site of identification and potential mobilisation against these stigmatising processes. Rather than mis-recognition and disidentification, the state of abjection depends on being mobilised and articulated as such, and hence requires over recognition from participants about the processes involved. She is thus cautiously optimistic about the potential of popular politics to be energised around contesting processes of abjection.

In Tyler's perspective, abjection is multi-dimensional, being produced by imperialist and nationalist projects as a means of marking the limits of governance itself. Economic marginalisation is thus associated with wider projects of abjection directed especially towards "outsiders", those located on the social and political margin, to whom the diktats of "states of exception" can be powerfully directed. It is in this context that the most marginal populations take on particular prominence, as a group which is held to be on the boundary of social acceptability, which therefore marks the contested boundary of the social body itself.

These four perspectives offer different accounts of the difficulties facing popular mobilisation. Currently, however, they are not matched systematic empirical research to explore their relative powers. The most interesting work adopts a case study 
approach usually rooted in analysing specific poor neighbourhoods, often using snowball or convenience sampling methods to derive a sample (e.g. Charlesworth 2000; McKenzie 2015; Evans 2008; Shildrick et al. 2013). Such research is very important but pre-selects on the basis of characteristics which can then be seen to define the findings (for instance, attachment to poor neighbourhoods). By selecting a disadvantaged sample by spatial criteria such as these, it is possible that the spatial and social analysis is unhelpfully conflated.

A key methodological advance in our paper is that we used the NCDS to draw a qualitative sample from a nationally representative sample. By extracting a sample of disadvantaged respondents, as defined by the extensive questions on economic, social and cultural factors which the NCDS contains, we are not forced to use spatial or neighbourhood criteria. The panel survey questions can thus provide a remarkable frame to select a group of respondents whose qualitative interviews which were conducted in 2010-2011 can be inspected with unusual analytical pay off. We recognise that this fieldwork took place 10 years ago; however, the fact that it occurred before recent political events such as the Brexit referendum makes it valuable in allowing us to examine precariat attitudes in a period before wider politicisation took place.

\section{The National Child Development Study}

The NCDS is probably the most prominent cohort study in the world and has traced the lives of respondents born in 1 week of 1958 through ten sweeps (see in general, Pearson 2016). Originating as the 1958 Birth Cohort Study, information was collected on more than 17,000 babies born in 1 week in 1958 (with a remarkable response rate of 98\%) to examine the social and obstetric factors associated with stillbirth and death in early infancy. Additional funding meant the same families were re-contacted 7 years later in 1965, and then subsequently in 1969, 1974, 1981, 1991, 2000, 2004, 2008, 2013 and most recently in 2020 (part suspended due to COVID). Apart from cohort members' themselves, information has been collected from their parent(s), teachers, and health professionals. During childhood, the cohort members took part in a variety of educational, medical and psychological assessments and examinations.

Our paper here uses data associated with the eighth wave which was carried out between 11th August 2008 and 18th May 2009, when respondents were age 50 in the vast majority of cases. A total number of 9790 respondents were interviewed, and more than 12,000 are still in contact with the study team. Our data consists of an additional qualitative component conducted on a sub-sample of the 2008-2009 respondents. Before 2008, qualitative methods had only rarely been applied to cohort members, and this proved the inspiration for a qualitative ESRC-funded "Social Participation" study which sought to conduct detailed qualitative interviews with a sub-sample of the NCDS. All the selected sub-sample had taken part in the main quantitative study, with the qualitative interviews taking place within 6 months of an individual's main age 50 at interview (see Elliott et al. 2010 for more details). In total, 238 cohort members were contacted, and 170 interviews were completed (86 men and 84 women), resulting in an overall response rate of $71 \%$. In 2010 , this original sample was boosted by an additional 51 Welsh interviews conducted by WISERD (Miles 2012) which increased the sample size to 221 in total. 
Our analytical approach is to draw on the interviews with 20 of the most disadvantaged of the 221 qualitative interviews in order to explore in depth the reasons for their political orientations ${ }^{1}$. We have pragmatically labelled these respondents as "precariat", that is to say from the most deprived of the NCDS respondents. This reflects the growing interest in using the term precariat (notably Savage et al. 2013; Savage et al. 2015), though we are not committed here to insisting that this group is defined specifically as a social class.

Since these NCDS members have not been approached to take part in a study specifically because they are seen to be in a deprived area, or because they are identified as "disadvantaged" and because they are NCDS cohort members, their accounts will not be coloured by the pre-conception that they have been specially picked out for such characteristics. In fact, NCDS members have been interviewed regularly throughout their lives and have a strong sense of themselves as being part of a key cohort study, findings from which have informed social scientific research as well as policy. When these qualitative interviews were conducted with them, they would not therefore have seen themselves as the subject of special interest because of their disadvantage, which adds to the value of their accounts. Given that so much research on the precarious uses a neighbourhood sampling approach which may generate responses associated with neighbourhood perceptions of criminality or marginality, and hence might unwittingly come to reinforce such perceptions, our approach here has major analytical advantages

Table 1 provides illustrative data drawn from the panel study to contextualise the socio-demographic characteristics of our selected precariat interviews compared to the nationally representative NCDS sample as a whole. It appears that our group of 20 specially selected interviewees do not resemble any stereotyped image of the "underclass", especially in terms of being defined as unemployed or living on public housing estates. In fact, only 2 of the sample rented their homes (less than the national average), and not a single one of these respondents was unemployed. They are nearly all economically active, mostly in a full time capacity, with a range of manual and routine clerical jobs, though ranging up to company secretary, planner and director (of a car body repair firm). They were mostly home owners. It was the low levels of pay which explain why these respondents are at the bottom of the first y-axis. With the exception of two men, the sample earns $£ 10$ per hour or less. Respondents were all white British (the NCDS itself, being composed of those born in the UK in 1958, has a low proportion of ethnic minorities).

To summarise Table 1, our respondents with the least economic and cultural capital are fundamentally poor working households and are no way part of a "welfaredependent" underclass ${ }^{2}$. We are also able to extract information about commonly used aggregate well-being measures for our 20 disadvantaged members to compare with the NCDS cohort as a whole (Table 2). These comparisons show again the value of our analytical approach, in that it is possible to compare our small number of interviews

\footnotetext{
${ }^{1}$ These were chosen taking the 20 respondents with the lowest scores on axis 1 from the multiple correspondence analysis conducted by Magne Flemmen as part of the analysis reported in Flemmen and Savage 2017 (though the cluster analysis is not reported there). The 20 respondents selected by this method are numbers 47, 115, 1098, 1307, 148, 189, 222, 224, 234, 244, 266, 276, 311, 377, 430, 461, 462, 481, 676, 736.

${ }^{2}$ We did use variables on whether households were in receipt of benefits in constructing the MCA "space". This finding is therefore not an artefact of our methods
} 
Table 1 Details of the 20 disadvantaged respondents from NCDS ( $N=20$ unless otherwise stated, where there is missing data)

\begin{tabular}{|c|c|c|}
\hline & Male & Female \\
\hline Economic activity & $\begin{array}{l}\text { Full time employee (8); full time self- } \\
\text { employed (2); permanently sick }\end{array}$ & $\begin{array}{l}\text { Full time employee (4); part time employee } \\
\text { (4); looking after home/family }\end{array}$ \\
\hline Occupations & $\begin{array}{l}\text { Archivist, bus driver, company secretary, } \\
\text { director, driver, estimator and planner, } \\
\text { foreman joiner, joiner, painter and decorator, } \\
\text { no occupation (2) }\end{array}$ & $\begin{array}{l}\text { Bookkeeper, administrator, catering assistant, } \\
\text { civil servant, courier, account executive, } \\
\text { supervisor, no occupation (2) }\end{array}$ \\
\hline $\begin{array}{l}\text { Mean net pay per } \\
\text { hour including } \\
\text { overtime }\end{array}$ & $£ 7.84(N=7)$ & $£ 6.65(N=8)$ \\
\hline $\begin{array}{l}\text { Income band per } \\
\text { hour (including } \\
\text { overtime) }\end{array}$ & $\begin{array}{l}£ 5 \text { and under }(2) ; £ 5.01-£ 10(3) ; £ 10.01-£ 15 \\
(2)(N=7)\end{array}$ & $£ 5$ and under $(2) ; £ 5.01$ to $£ 10(6)(N=8)$ \\
\hline $\begin{array}{l}\text { Highest } \\
\text { educational } \\
\text { qualifications }\end{array}$ & None (3); NVQ1 (3); NVQ3 (5) & None (2); NVQ1 (2); NVQ2 (4); NVQ3 \\
\hline $\begin{array}{l}\text { Partner's } \\
\text { economic activity }\end{array}$ & $\begin{array}{l}\text { Temporarily sick (2), full time paid employee } \\
\text { (6), part time paid employee }\end{array}$ & Full time employee (7) \\
\hline Housing tenure & Owns outright (2), owns with mortgage (9) & $\begin{array}{l}\text { Own outright (1), own with mortgage (6), } \\
\text { rent ( } 2 \text { ) }\end{array}$ \\
\hline
\end{tabular}

with the representative sample as a whole. The comparison is highly revealing, indeed surprising. In general, our 20 respondents report higher levels of well-being than the NCDS respondents as a whole. This is a counter-intuitive finding which we try to make sense of when turning to our analysis of the interviews. Indeed, 18 out of the 20 precariat sample say they "usually get what they want out of life" which is considerably higher than the nationally representative patterns. They also report significantly higher than average scores on the quality of life on the CASP-19 measures which capture a basket of measures indexing quality of life, and they have a much lower "malaise" score than the NCDS as a whole. Their mental well-being scale is slightly higher than the population as a whole. This is itself prima facie evidence that even though our measures entail that we have chosen the 20 respondents with the least economic and cultural capital, this does not clearly translate into this group appearing to have the greatest problems of well-being or malaise more generally-there is no simple process of spill over from lack of economic and cultural capital to lower levels of reported well-being.

It is therefore absolutely clear that those 20 individual respondents who appear to be the most deprived, according to our multidimensional analysis of economic and cultural capital, do not appear to conform to popular "Benefit Street" or "underclass" stereotypes.

Table 2 Disadvantaged at sample compared to NCDS population as a whole

\begin{tabular}{lll}
\hline Measure of well-being & $\begin{array}{l}\mathbf{2 0} \text { precariat } \\
\text { interviews }\end{array}$ & $\begin{array}{l}\text { NCDS responses as a } \\
\text { whole }\end{array}$ \\
\hline Mean Edinburgh-Warwick mental well-being scale & 50.9 & $49.26(\mathrm{~N}=8642)$ \\
\% self-reporting very good or good health & 85 & $33.3(\mathrm{~N}=9626)$ \\
Total malaise score $>$ 2 & 70 & $59.1(\mathrm{~N}=8616)$ \\
\% overall CASP 19 quality of life score 30+ & 80 & $77.6(\mathrm{~N}=9599)$ \\
$\begin{array}{l}\text { \% thinking they usually get what they want out of } \\
\text { life }\end{array}$ & 90 & \\
\hline
\end{tabular}


In addition to our 20 disadvantaged respondents, we also selected a random sample of 15 individuals from the NCDS to include in the content analysis of the narratives. We conducted computer-assisted analysis using the QDA Miner and Word Stat software packages. The coding scheme organised the narratives under the general categories of relationships, sentiment and assessment, habits and practices, identity and life course. These categories emerged from inductive coding based on linguistic similarities in individuals' narratives. Sentences were analysed and clustered according to word similarity. Codes emerged from these clusters as well as keyword queries and were posteriorly grouped into the five categories above. This allowed a balanced coding across the disadvantaged and control groups, and thus allows for content analysis with reduced risk of coding biases.

\section{The politics of the excluded}

We now turn to interpret the interview material to explore the political orientations and engagements of our poor sample. Here, our analytical task is to consider in their own words what these particularly precarious respondents identify about their class position and to reflect on what kind of political consciousness they have.

An important starting point is the question which was asked towards the end of the interview probing what social class the respondents thought they belonged to. Here, there were two main kinds of response: the first being to deny that the respondent was in a class (nine respondents) and the second being to claim a working class identity (seven respondents). Two saw themselves as middle class, one as "ordinary", and another as "working middle".

Those who saw themselves as not in a class generally recognised the existence of class divisions but saw this as a positive statement that class divisions were not relevant to them (along the lines discussed in Savage et al. 2001). When asked if he belonged to a social class, P115 responded:

Absolutely not, no. I suppose we were brought up in a working class family but I've never felt like a working class really, I don't know what that means, so no.

I think that's really interesting, so you've kind of felt the label on you but you didn't sort of--,

Didn't feel I fit the criteria at all, no. I don't think any of us do really, we're all--, my sisters all went to the grammar school and have all got themselves very good jobs, from one who's a doctor, a scientist she is, down to a social worker and I've always felt like I belong with them and I don't feel like anything else really.

For P377, a strong sense of not belonging to a class was associated with a sophisticated understanding of class divisions

At one stage I suppose when I was younger I always saw myself as working class. Never saw myself as upper class, you know, like these people who live in these big 
houses and whatever and feel they're better than everybody else, snobby. And now my social class is "no social class", I'm in my own social class. I do whatever I want, no-one bothers me, I don't get involved with politics or anything like that "cause it's all a load of rubbish and, no, I've got my own class".

Having no class is here a statement against the power of class divisions, a means of asserting self-hood, somewhat along the lines that Beck and Giddens lay out. In other cases too, articulating a "no class" identity could be a means of making an egalitarian statement. P676 vehemently denied belonging to a class, "because I'm sorry we're all the same .... no matter what. You might have more money than me but this is something my ex-father-in-law always told me, he said, "Nobody's better than you. They're the same as you but nobody's better than you," and I do live by that as well".

This theme about being as good as anyone else and emphasising democratic individuality was common amongst our sample. It represented an awareness of class inequalities and the way that class could be used to stigmatise, whilst insisting on a fundamental human equality which transcended such divisions. For P481, "The way we go--, the way we come in is the way we go isn't it? Everybody's the exact same".

This sense of individual pride or what has been called elsewhere "rugged individualism" (Savage et al. 2001) is articulated clearly by P266, who insisted that she was "working class basically, certainly not middle or upper". She explained her views by adding:

I've always been a grafter, like. Never had that much money to be, you know, up with the hoi polloi and all that, you know? I just get along, if I've got the money I'll get it, if I've not got the money don't get it. I'm not one of these who go out--, I've never had a credit card, never would, the wife's exactly the same. It's basically, if you want it, save for it. Once you've got it, get it, if not, forget it. I think there's a lot too much of this, you know? This is why they've got themselves into trouble in the first place, all this borrowing and things. I'll be just glad when this is paid off, you know, then we can think about moving later on and see how the market goes, but you know once that's paid off, because that's the biggest payment, isn't it, your house? Once that's paid off then it's clear and I'm glad I got it when I did because I hate to think what they're paying nowadays, mortgage wise, it's a nightmare for them.

As we can see, relational contrasts with other classes were often evoked even whilst denying that the respondent belonged to a class. For this reason, there is a point of connection with those who did claim to be working class. There was generally a strong sense from all respondents that they were clearly differentiated from those above them in the social order. For some, this negative identification against "upper" classes was very strongly felt and more salient than identification with the working class itself. P461 stated that:

I would say working middle.... I see myself as a working hard person, trying to provide for a family, because I come from a working background, I don't see myself upper because I don't think I class myself as being a snob, a label or anything associated with that type of person, associating with free loading 
money. I would say that I'm--, definitely I'm working class, down to earth if I'm honest. (P461)

There was thus no doubting a keen awareness of relative disadvantage. Runciman (1966) famously argued that the reference groups of the working class tend to be limited and only focus on those immediately above them. In fact, as the examples above indicate, this is by no means so clear amongst our sample, where their reference groups are often much higher in the social structure (and see also Savage 2005 who detects similar refrains evident amongst "affluent workers" during the 1960s). There are some cases where respondents compared themselves with those in slightly more elevated positions within a broadly working class position, rather than with any kind of upper class elite.

Other studies have shown how the poor dis-identify from poverty and often stigmatise those who they see as being "really" poor (Shildrick and MacDonald 2013). This was less marked amongst our sample, perhaps because our multidimensional measures do not pick out those necessarily located in poor or slum neighbourhoods. In general, there is little direct evidence from these accounts of direct dis-identification or misrecognition from class, and certainly not regarding the projection of identities onto more "respectable" identities. However, this did not mean that the respondents had a clear sense of class boundaries, or politics. Some ambivalence about what a working class identity entailed was common.

This uncertainty about handling class blended into motifs that one should treat people as people, and not judge them according to their class. What kind of political consciousness class was evident? In a few cases, this was clear and direct, notably from P189 who articulated a strong sense of resistance to upper class snobbery. This account is worth reporting at length since it is indicative of a highly sophisticated awareness of class:

In my job I see people who are obsessed with class, absolutely. I know the likes of Lady...., the old money, they don't give a shit because money's nothing to them, it's the ones, the aspiring ones. You know, I go to people's houses and they've got Punch cartoons from 1920 up and they're usually in the toilet for some reason, these Punch cartoons it's like everybody's sitting pointing at somebody, somebody's going, "Oh we've got the fish knife for beef," oh, so what, if somebody makes a faux-pas, let's all laugh about it, you know, and people talk about other people all the time and how they--, I hear this all the time with new money and old money and [bidding each other out (?) inaudible] and you think--, Life's too short for that, it really is.

Did you feel you belonged to a particular social class when you were growing up or have you always felt like this?

Oh, I remember thinking when I was a teenager I thought I was some sort of working class hero, John Lennon song, you know.... I was right in to the 
Clydesiders and I've always been obsessed with--, or interested or obsessed with the Soviet Union and the experiment that went wrong, I see a lot of--, Joseph Stalin was pretty much a... president who was ruthless, I've seen it in various--, I know a couple of presidents of bike clubs and that, aye I find that quite interesting.

P189 unusually is aware of the Scottish socialist history, which he deploys positively to criticise upper class pretentions. Yet, ultimately, he distances himself from an overt commitment to socialist politics, which he attributes to learning the lessons of Soviet history. A similar awareness of socialist politics comes from P102:

Working class, because of the job that I do and the money that I earn. Yeah, I'm working class. I've always said to my son, we're working class but we're not common and that's how I see myself.

You talk about the job you do, your work as a manager and you work with IT stuff.... So that's not sort of classically working class, is it?

No, it's more white-collar but I still have my roots. I used to be a socialist, I try to be. Things have changed a lot, politics. That's my roots, that's what I am.

And have you always felt that way?

Yeah, yeah. I don't like snobbery. We're all the same as far I'm concerned. I treat people as I find and they're all right with me, no matter who they are, I'm all right with them. Yeah. I don't look down on people, I don't expect them to look down on me. So yeah, working class.

Okay. Did your dad's politics influence you in that sense?

Very much so, yeah. My dad was a big communist...... Yeah, that's why it's \{P311's FIRST NAME\} with a \{INITIAL LETTER\}, for \{FAMOUSCOMMUNIST\}. But I'm not like that as such. Great in theory, but not in practice, communism.

Here, as with P189, we see an interest in the historical aspects of socialist politics whilst also rejecting its contemporary relevance. These two were the only respondents with the political awareness to make links to the Labour movement, or indeed any other organised political force, and it is revealing that these are presented historically, as belonging to the past.

Alongside the downplaying of strong political identities, there was also little indication of involvement in formal political activity (Table 3). The panel data here is also 
Table 3 Institutional involvement of NCDS panel members

\begin{tabular}{lllll}
\hline & $\begin{array}{l}\text { Male } \\
\text { disadvantaged }\end{array}$ & $\begin{array}{l}\text { Male (entire NCDS } \\
\text { sample) }\end{array}$ & $\begin{array}{l}\text { Female } \\
\text { disadvantaged }\end{array}$ & $\begin{array}{l}\text { Female (entire NCDS } \\
\text { sample) }\end{array}$ \\
\hline $\begin{array}{l}\text { Age 23 } \\
\text { involvement }\end{array}$ & 9 (out of 10) & $80 \%$ & 4 (out of 6) & $61 \%$ \\
Age 33 & $2(11)$ & $29 \%$ & $2(5)$ & $44 \%$ \\
Age 42 & $1(11)$ & $24 \%$ & $2(9)$ & $37 \%$ \\
Age 46 & $5(11)$ & $59 \%$ & $4(9)$ & $49 \%$ \\
Age 50 & $5(9)$ & $65 \%$ & $2(9)$ & $78 \%$ \\
\hline
\end{tabular}

revealing, as we can trace the organisational involvement of our 20 respondents over previous waves of the survey, at ages $23,33,42,46$ and 50 . If we look at the aggregate patterns, we can note striking shifts in the extent to which respondents were involved with different kinds of organisations. Our disadvantaged sample was as likely as the sample as a whole to be in organisations when they were 23, by the ages of 33 and 42 are much less likely than the NCDS as a whole to be engaged in organisations. However, by ages 46 and 50, whilst male participation in organisations increased, the gap in participation between the female disadvantaged and their NCDS counterparts increased.

At age 46, only two of the disadvantaged women reported any associational activity in their NCDS survey return. When we interviewed them in depth a few years later, the situation was even more limited. This may be explained, at least in part by the type of organisational involvement of men and women. Men are more inclined to join clubs or associations based on their hobbies or interest, whether they are political, sports, music or of other sort.

Men seem to be adapting their degree of their involvement in organisation to particular stages of their lifecourse, so withdrawal is not necessarily permanent, as they are able to pick up interests they had momentarily left aside to leave room for other demands on their time. Women's participation, quite on the contrary, was very much linked to external motivations, namely their parenting roles when children were young, but once their families grow up and these obligations have been fulfilled, all apparent reasons for their involvement in organisations disappear.

No, not really. I'm religious to a degree, but church--, the girls were brought up Catholic because my ex-husband was a Catholic. So I did take them to church and we did a lot in connection with school and church, when they were at $\{\mathrm{SCHOOL1 \}}$, which is a primary trust school. But then it was their choice after that, once they left there, whether they wanted to carry on going to church. And so I just supported them when I needed to, for that time. Even though I wasn't Catholic I still took them to Catholic church. Politically, no, I really don't feel anything--, I mean I have my opinions on what I think that somebody's making an absolute mess of something, but I don't--, I'm not--, you know. Some people have very strong opinions but I don't at all (P244 Stable Working Class).

At the age of 50 years, most women had entirely disengaged from formal associational life, and with the exception of P430 who belongs to a trade union, there is little evidence of politically oriented associativity. 
Our findings therefore seem clear. Our respondents were usually aware that they were placed at the bottom rungs of the social order, and in many cases demonstrated a clear relational class consciousness which contrasted themselves with those higher up the social structure. Contrary to Bourdieusian perspectives that there will be "mis-recognition" and "dis-identification", there was little evidence that this awareness directly evoked social shame or stigma, in fact, there was considerable evidence of a kind of earthy pride in not being in a more privileged social position. At least on the face of it, there was no direct articulation of shame or moral inferiority as defined by their social position. Class was not usually seen as a politicised label, which evoked distinctive political perspectives, but was rather identified as culturally salient in terms of one's preparedness to treat people as individuals and not be snobbish. This explains why the language of class was sometimes ambivalently used as it seemed to have the connotation that one did not judge people as individuals. The limitations to associational life was not understood by individuals as a result from disenchantment from the decline of communal solidarity that they may have experienced through their life courses, but it was interpreted as the result of highly individualised demands on their lives, and the challenges that posed to engaging in collective endeavours.

\section{Life course inequalities, contentment and abjection}

Having argued against the idea that there is "misrecognition" amongst our precariat sample, we now pursue the related argument that it is the individual experience of suffering and abjection which is more salient. Here, we use a content analysis of the transcripts in QDA miner to provide a more formal analysis of the terms that these respondents used.

Figure 1 shows that the differences between the precariat and the control group were actually modest. It is too stark to juxtapose a traumatised precariat against a more contented control group. Having said this, there were modest differences. Whereas in the control group there is a balance between positive and negative experiences (50\%), the proportion of negative to positive experiences is somewhat higher amongst the

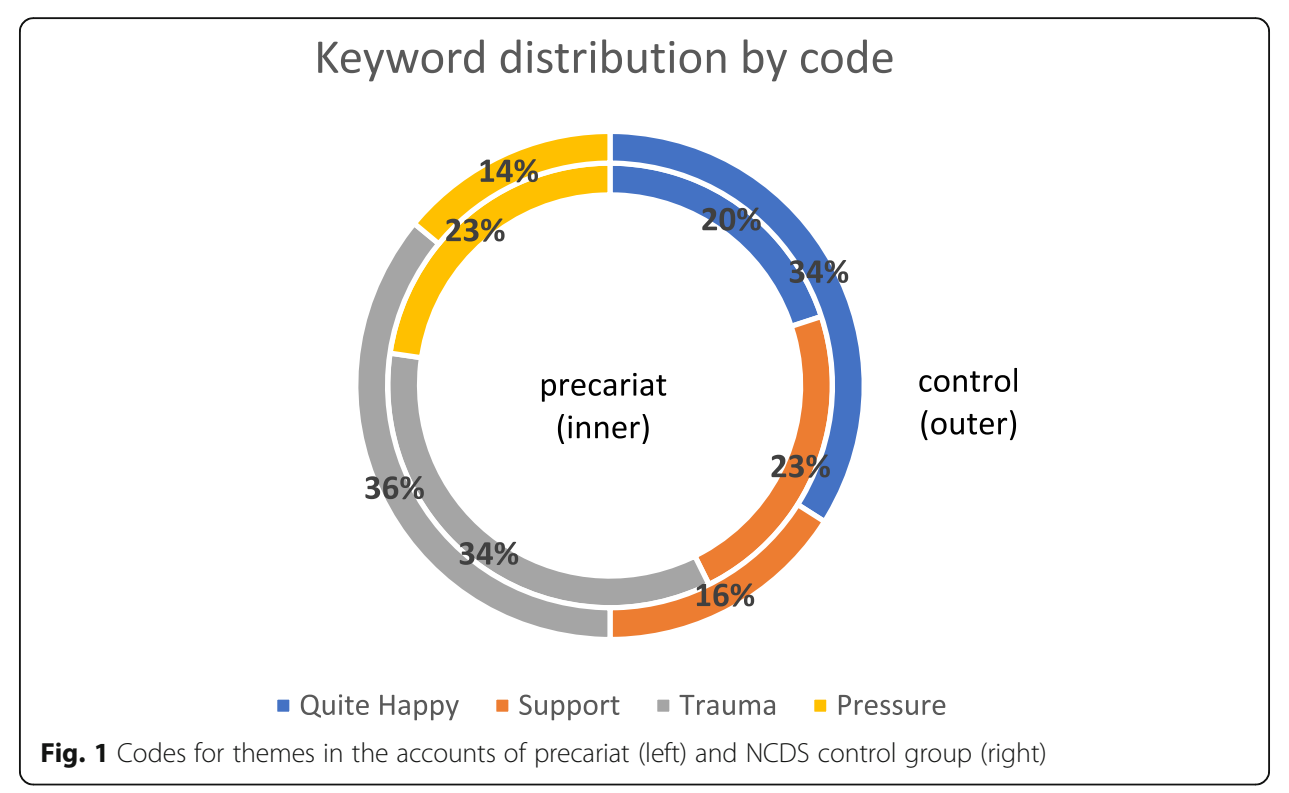


precariat (57.4\%). These negative experiences arise from long-term pressurising circumstances such as unhappy marriages, extended periods of pressure at work or caring for an ill child. These non-traumatic yet extremely problematic circumstances may be well contributing to the overall perception of relative disadvantage expressed in the class identification narratives.

Not really great with computers in this day and age considering the kids are all--, do you know what I mean?

Yeah.

I might struggle if I have to go somewhere else to work, when it comes to being a whizz kid on a computer. I do all right in my own job but-- (P224)

Here, P224, one of the participants that does not report seriously disruptive life events, accounts for the more subtle but sustained pressure of becoming technologically obsolete and the risk that entails for her job security. In the same vein, P276 speaks about her husband's-and by extension her-pressure to secure a dignified pension after years of health problems, paying off the divorce from a previous marriage, periods of unemployment and increasingly reduced wages.

$\{$ HUSBAND\}--, it needs sorting out at the moment, and it's been so cold. And obviously he does a lot of hours, so I just--, he puts himself under so much pressure trying to do everything, and I was telling him off this weekend actually for making it a trial, having a day off, you know, feeling guilty about relaxing, putting your feet up and watching the rugby. You know, I said, "For goodness sake, you can't do it, you've got to enjoy it. You'll get to the allotment and do what you want when the weather improves and you feel more like you can do it." (P276 Stable Working Class)

A more extreme case of sustained pressure is represented by P461, who has acted as a carer for her ill father, aunt, husband, daughter and grandson. Her narrative denotes simultaneously a remarkable mastery of the logistics of caring for multiple family members alongside awareness of the physical and emotional stretch required by such an operation.

we've been thrown so many hard blows in life us as a family, I mean my youngest daughter, she was born, she was born early, but only to discover she was born with one kidney at ten, then at 22 they tell us she's only got one ovary, $[\ldots]$ and how are you supposed to deal with things like that, that you've produced a baby that's not right [...] I'd say maybe the less stressful point is, is having \{DAUGHTER2\} being moved up nearer me, so that's taken a bit of the pressure off, because \{GRANDSON1\} was going to the hospital every week and they couldn't--, she couldn't take \{GRANDSON2\} with her in the ambulance transport so it meant I had to do a round trip, you know, I was leaving here at half past six in the morning and going on for two years, but I would 
say probably them moving up here, it has been a turning point, but not a turning point in my life, but in a turning point as in being able to deal with problems and not being able to, you know--, having to go and leave Dad for such a long time, it's made life a bit easier since March (P461 Working to Intermediate Class).

These cases express, to different degrees, the internalisation of the pressures and demands in their risk biographies. It is always them who must take responsibility for what has gone wrong-notably P461 takes responsibility for producing a "baby that's not right" - and it is up to them to find the resources and strategies to set things back to their right course whether that is improving their computer skills, finding nukes in time to decompress from sustained financial struggles or moving houses to facilitate the logistics of caring for multiple family members. They never mention reliance on anything else other than their own capabilities for sorting out these conundrums, demonstrating that individualisation is not reserved for more affluent and advantaged members of society, but it is also deeply engrained amongst those in more precarious situations.

According to Derxx (2013) and drawing from van Praag and Baumeister, meaning in life necessitates: (i) purpose, a connection between the present and something of "positive value in the future", which may be an external goal but it can also mean inner fulfilment; (ii) moral worth that provides our actions with legitimacy by the community; (iii) self-worth derived from our comparison with others or from our identifying with a community; (iv) competence or agency providing a sense control over events, whether that is through adapting the environment to our needs or by performing an interpretive exercise where a sense of control comes from understanding and making sense of things. To complete the frame of needs for meaning, Derxx then draws on the work of Smaling and Alma which focuses more on the communal aspects of meaning, namely, (v) comprehensibility, which provides some orientation as to why things happen and provides some stability to the world; (vi) transcendence which includes connectedness to others or the awareness of being part of something bigger than oneself; and (vii) sense of wonder and excitement, something that stirs our curiosity and prevents life from being boring and monotonous.

The code "quite happy" was created to account for situations where despite discomfort, difficulties and even duress, individuals manage to come to terms with their circumstances, and indeed to be "quite happy" with how things turn out in the end. Figure 2 shows the proximity of quite happy to other aspects of life which were mentioned by respondents ${ }^{3}$. When speaking about their lifecourse, P1098 and P481 refer to the relationship between income and housing arrangements:

The only thing if we moved would be is if we won the--, you know, won a nice lot of money, that's the only--, we're quite happy here, we like it here, it's nice. It is quite safe, apart from the trains--, the buses, it's nice and quiet, you haven't got a lot of kids running around shouting and that and it's--, but next door have got two children, you don't even know they're here, only when they play outside and that's

${ }^{3}$ The proximity is calculated using the Jaccard coefficient in a window of ten paragraphs. The Jaccard coefficient weights the co-occurrence of quite happy and other codes in the ten paragraph window, against independent occurrences of the codes. 


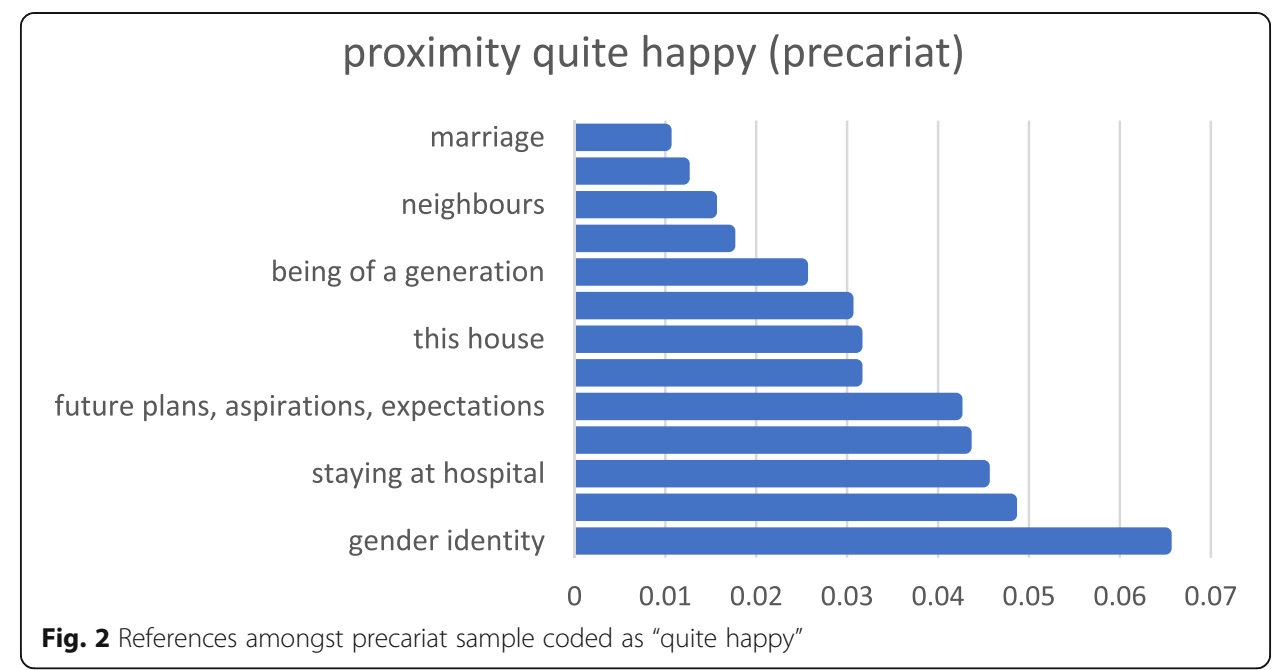

it, but no that's the only reason. We would never--, I don't think we'd ever move. My wife loves it here, she's from Birmingham originally, so--, and she says--, she feels $\{$ PLACE3\}'s her home now, she's been down here 20--, oh 20 odd years [...] (P1098 Intermediate to Working Class).

P1098 briefly nods to aspirational dreams of climbing the house ladder, but then quickly shifts his narrative to one of identification with the area. This narrative subsumes negative assessments about housing opportunities. The narrative of P481 makes an even sharper turn in the direction of reconciling with unfulfilled aspirations:

my partner I've been with for 11 years now and he could never afford to buy a home for us, so I've always lived here, Mum and I share the house and we're quite happy, he comes and visits and comes back again and we go off on a holiday together but, you know, I'm quite happy with that (P115 Intermediate to Service Class).

Overcoming life difficulties provides a sense of contentment and serenity, but amongst women, it may also come with negotiations about recuperating youthful vigour and sexual appeal that seemed lost, at least for some time. This is the case of P148, who after several traumatic experiences in her teens, twenties and thirties, spent her much less turbulent forties seeking sources of enjoyment that not necessarily match those of her memories from 30 years back.

I think so, yeah, yeah. I think as you reach--, I had a good time when I was 40, and that was before I met $\{$ HUSBAND\}. I met $\{$ HUSBAND $\}$ I was 42 'ish, so sort of 40 , 41, 42 I was going out, enjoying myself again as I did when I was 20, 21, 22, so 20 years later I was doing the same things again but they didn't have the same appeal, and I think that was because I was older, you know, mentally, more mature, you know what you're doing this time around, you know what pitfalls to avoid and--, yeah but in my 40s--, early 40s I was doing the same as I was doing in my 20 s, but now I'm in my 50s I couldn't think about doing that again, I'm just happy and content with my life as it is (P148 Working to Service Class). 
For P461, refocusing on herself after decades of being a carer to her ailing father, her ill children, her severely depressed husband and coping with her own mental health assumes the form of noticing her body and dress.

A woman... I don't see myself as anything else other than a woman. I wouldn't say I'm one of these sort of glamorous type women that has to have their make-up on and all dolled up, you know, and everything like that. I was never one for that, even as a teenager. I'm quite happy with myself, as being a female, okay, I'm not happy with what's going on round about me, as in bodily wise because of your age, but other than that I'm quite content really [...] I would say what you do, you try--, as you get older, you try to be, not more feminine, but you try to dress slightly different, but whether--, me being in the scenario, you cannot go about with big frilly blouses on and lovely wee skirts and your tights and your shoes because when you're with these--, these kids you've got chocolate from here to here, so you don't really do that, so what I try to do is on the days off that I've got, I put on my dress and, you know, a nice cardigan and my shoes and--, and I do that at the weekends and things, so I get more dressed up at the weekends and I enjoy that. (P461 Working to Intermediate Class).

Those in our sample of precarious individuals are aware of their disadvantage, but they embrace their struggles and traumas because they appeal to their frame of meaning, to their capacity to overcome, to larger gender identities which transcends their own physical changes, to wonder over their recently found maturity and the serenity that come with it.

Derxx draws from the work of Clifford Geertz to explain why a frame of meaning matters:

the problem of suffering is paradoxically no how to avoid suffering but how to suffer, how to make of physical pain, personal loss, wordly defeat, or the helpless contemplation of other's agony something bearable, supportable - something as we say, sufferable.

In this sense, owning disadvantage and trauma would make it more sufferable, more morally justifiable and perhaps even moral worth is a route to enhancing self-worth. Throughout the lifecourse, the precarious balanced their disadvantage with positive valuations of life which in the end makes them likely to be "quite happy". In an individualised society, abjection places these participants at the margins of the socially acceptable-barely able to maintain a life of their own-and thus their moral stance facing adversity gains relevance as an individualised political response to external labels, and affords a stronger footing on the internal "acceptable" side of society.

\section{Abjection: the politics of personal trauma}

In the "Life course inequalities, contentment and abjection" section, we reflected on the power of individualised narratives and the way that these problematize influential sociological arguments which fail to fully do justice to the messy narratives of the NCDS respondents. These men and women do not substantially dis-identify from class. 
They are not predisposed towards collective political engagement and rarely exhibit a strong sense of political radicalism. They are not obvious candidates for formal political mobilisation. To treat this as a form of false consciousness however fails to grasp the internal logic of the accounts of respondents and take their own words and views seriously.

In their important study, Shildrick and MacDonald (2013: 291) emphasise that their poor respondents in northern England emphasise their normality. "In presenting themselves as largely unremarkable, in rejecting the label of poverty, in stressing pride in coping with hardship, research participants constructed a self-identity in contrast to a (usually) nameless mass of "Others" who were believed, variously, to be work-shy, to claim benefits illegitimately and to be unable to "manage" and to engage in blameworthy consumption habits". We have certainly seen strong refrains of this kind amongst our sample, and it is indeed a key feature of their insistence on being "just working class".

However, we argue, following the frequency of the codes revealed in Fig. 1, that we should also be aware of the central role of trauma in many of these respondents' lives. This articulates a self-identity with modes of abjection which presents respondents as victims, disabled and disempowered. To this extent, modes of abjection were narrated and "owned" by the respondents. However, rather than leading to a politics of despair or fatalism, these were often articulated into narratives of personal reconciliation and recovery, and the recovery of a certain kind of "normality".

Table 1 lists the 20 respondents, their characteristics and the extent to which they narrate lives marked by some kind of "trauma". We have coded these cases red when these respondents indicate that certain traumas are life-defining, yellow when there is a relatively serious matter causing considerable anxiety, and green where no, or only limited, trauma is evident from the respondent's testimony.

Table 4 reveals that four report major personal traumas during the course of their lives-which overshadow their identities and give meaning to them-and a further eleven identify major personal difficulties which they discuss at length. Only three present an account of general personal well-being and a straightforward sense of ease with their lives.

We can note at the outset that these accounts are "freely" given to interviewers who have not met the respondents on previous occasions. Rather than being elicited through subtle teasing out over tense and fraught discussions, respondents openly articulate their trauma, difficulty and reconciliation. To this extent, abjection is "owned" by respondents. These events tend to both "individualise", in making respondents feel solitary and isolated, and also produce a personalised sensibility which focuses on "ordinary" strategies for developing security which are deemed to be outside the realm of ordinary politics.

The two main traumas which respondents identified are of abusive personal relationships and serious ill-health, both of which can have a life defining quality. Most of the respondents we interviewed had managed to place their life on a more secure footing after serious personal problems in their $20 \mathrm{~s}$ and $30 \mathrm{~s}$, and to this extent, they had achieved a certain social balance which they felt gave them a degree of security. The most harrowing cases are instructive. 
Table 4 Interviews with precariat, indicating key life factors, and extent to which narrative is traumatic

\begin{tabular}{|c|c|c|c|c|c|}
\hline ID & $\begin{array}{|ll|}\text { Tenure } & \& \\
\text { Length } & \text { of } \\
\text { residence } & \\
\end{array}$ & $\begin{array}{l}\text { Occupational } \\
\text { history }\end{array}$ & Household & Education & Trauma details \\
\hline $\begin{array}{l}\text { P189 } \\
M\end{array}$ & $\begin{array}{l}\text { Owns with } \\
\text { mortgage } 20 \\
\text { yrs }\end{array}$ & $\begin{array}{l}\text { Painter and } \\
\text { decorator (prev } \\
\text { DHSS worker }\end{array}$ & $\begin{array}{|lr|}\text { Single } & \text { parent, } \\
\text { son } & 11, \\
\text { daughter } & 18 \\
\text { (uni) } & \\
\end{array}$ & apprentice & $\begin{array}{l}\text { Divorce, crime, } \\
\text { violence, drugs, } \\
\text { problems with } \\
\text { children }\end{array}$ \\
\hline $\begin{array}{l}\text { P461 } \\
\text { F }\end{array}$ & $\begin{array}{l}\text { Own house } \\
\text { (originally } \\
\text { parents) }\end{array}$ & $\begin{array}{l}\text { Does not work } \\
\text { now, used to be } \\
\text { retail manager }\end{array}$ & Father, husband & Left 16 & $\begin{array}{l}\text { Demands of } \\
\text { ailing father, } \\
\text { husband } \\
\text { severely } \\
\text { depressed, } \\
\text { sexual attack, } \\
\text { IIl children } \\
\end{array}$ \\
\hline $\begin{array}{l}\text { P736 } \\
M\end{array}$ & $\begin{array}{l}\text { Owned } \\
18 \mathrm{yrs}\end{array}$ & \begin{tabular}{|lr} 
Army, & security \\
services, then \\
archivist ror \\
solicitors
\end{tabular} & Wife and kids & $\begin{array}{ll}\text { Left } & \text { school } \\
17 & \end{array}$ & $\begin{array}{l}\text { Cancer } \\
\text { Heart attack }\end{array}$ \\
\hline $\begin{array}{l}\text { P430 } \\
F\end{array}$ & $\begin{array}{l}\text { Private } \\
\text { tenant } 4 \text { yrs }\end{array}$ & Off sick & Partner & No quals & $\begin{array}{l}\text { Seriously ill, off } \\
\text { work, } \\
\text { emotionally } \\
\text { bullied, abusive } \\
\text { father, heart } \\
\text { condition, ill } \\
\text { aunt } \\
\end{array}$ \\
\hline $\begin{array}{l}\text { P148 } \\
\text { F }\end{array}$ & $\begin{array}{l}\text { Owns with } \\
\text { mortgage }\end{array}$ & $\begin{array}{l}\text { Financial } \\
\text { services }\end{array}$ & $\begin{array}{ll}\text { Self } \\
\text { husband }\end{array}$ & $\begin{array}{ll}\text { Left school } \\
16\end{array}$ & $\begin{array}{l}\text { Pregnant at 16, } \\
\text { divorce, } \\
\text { abused, son } \\
\text { died }\end{array}$ \\
\hline $\begin{array}{l}\text { P130 } \\
7 \\
F\end{array}$ & $\begin{array}{ll}\text { Rents rural } \\
\text { house }\end{array}$ & $\begin{array}{l}\text { Former } \\
\text { components } \\
\text { manufacturer }\end{array}$ & $\begin{array}{l}\text { Husband and } 24 \\
\text { year old son }\end{array}$ & $\begin{array}{l}\text { Left school } \\
16\end{array}$ & $\begin{array}{l}\text { Divorced, made } \\
\text { redundant, } \\
\text { sister has } \\
\text { special needs }\end{array}$ \\
\hline $\begin{array}{l}\text { P47 } \\
\text { M }\end{array}$ & \begin{tabular}{|l|}
$\begin{array}{l}\text { Owns old } \\
\text { family house }\end{array}$ \\
\end{tabular} & $\begin{array}{l}\text { Car body repair } \\
\text { firm director }\end{array}$ & daughter & \begin{tabular}{|l|l|} 
Left school \\
16
\end{tabular} & \begin{tabular}{|l|}
$\begin{array}{l}\text { Traumatic } \\
\text { divorce, }\end{array}$ \\
\end{tabular} \\
\hline $\begin{array}{l}\text { P115 } \\
F\end{array}$ & $\begin{array}{l}\text { Inherited } \\
\text { house from } \\
\text { family }\end{array}$ & Shop asst & $\begin{array}{l}\text { Partner and } \\
\text { mother }\end{array}$ & $\begin{array}{ll}\text { Left school } \\
16\end{array}$ & $\begin{array}{l}\text { Very positive } \\
\text { account of } \\
\text { community life } \\
\end{array}$ \\
\hline $\begin{array}{l}\text { P462 } \\
F\end{array}$ & $\begin{array}{l}\text { Owns with } \\
\text { mortgage }\end{array}$ & Bank worker & $\begin{array}{l}\text { Husband and } \\
\text { daughter }\end{array}$ & $\begin{array}{ll}\text { Left school } \\
16\end{array}$ & $\begin{array}{l}\text { Caring } \\
\text { responsibilities, } \\
\text { alcoholic } \\
\text { mother, } \\
\text { relation with } \\
\text { brother } \\
\end{array}$ \\
\hline $\begin{array}{l}\text { P481 } \\
M\end{array}$ & $\begin{array}{l}\text { Owns with } \\
\text { mortgage }\end{array}$ & joiner & Wife & $\begin{array}{|ll|}\text { Left school } \\
16\end{array}$ & $\begin{array}{l}\text { Marital break } \\
\text { up, hesitancy }\end{array}$ \\
\hline $\begin{array}{l}\text { P676 } \\
F\end{array}$ & $\begin{array}{l}\text { Owns with } \\
\text { mortgage }\end{array}$ & Care assistant & Husband & $\begin{array}{|ll|}\text { Left school } \\
16\end{array}$ & \begin{tabular}{|ll} 
No major & mauma \\
\end{tabular} \\
\hline $\begin{array}{l}\text { P276 } \\
\text { F }\end{array}$ & Rents & $\begin{array}{l}\text { Hairdresser, } \\
\text { Seamstress }\end{array}$ & Husband & $\begin{array}{ll}\text { Left school } \\
16\end{array}$ & $\begin{array}{l}\text { Divorce, illness, } \\
\text { husband } \\
\text { severely ill, } \\
\text { unemployment } \\
\text { and husband's } \\
\text { unemployment } \\
\quad \text { financial } \\
\text { pressure }\end{array}$ \\
\hline $\begin{array}{l}\mathrm{P} 224 \\
\mathrm{~F}\end{array}$ & $\begin{array}{l}\text { Owns with } \\
\text { mortgage }\end{array}$ & $\begin{array}{l}\text { Letters } \\
\text { administrator }\end{array}$ & Self & & \begin{tabular}{|ll} 
No major \\
trauma
\end{tabular} \\
\hline $\begin{array}{l}\text { P377 } \\
M\end{array}$ & Owned & Off sick & Wife & apprentice & $\begin{array}{l}\text { Break up with } \\
\text { partner, cancer }\end{array}$ \\
\hline $\begin{array}{l}\mathrm{P} 222 \\
\mathrm{M}\end{array}$ & $\begin{array}{l}\text { Owns with } \\
\text { mortgage }\end{array}$ & $\begin{array}{l}\text { Company } \\
\text { secretary }\end{array}$ & \begin{tabular}{|ll}
$\begin{array}{l}\text { Wife, } \\
\text { (university } \\
\text { holidays) }\end{array}$ \\
\end{tabular} & $\begin{array}{l}\text { O levels, } \\
\text { apprentice }\end{array}$ & \begin{tabular}{|l|} 
Financial \\
pressure, heart \\
condition \\
\end{tabular} \\
\hline $\begin{array}{l}\mathrm{P} 234 \\
\mathrm{M}\end{array}$ & $\begin{array}{l}\text { Owns with } \\
\text { mortgage }\end{array}$ & Engineer & Wife & $\begin{array}{ll}\text { Left school } \\
16\end{array}$ & \begin{tabular}{|l|} 
Made \\
redundant, \\
sustained \\
pressure at \\
work \\
\end{tabular} \\
\hline $\begin{array}{l}\mathrm{P} 244 \\
\mathrm{M}\end{array}$ & $\begin{array}{l}\text { Owns with } \\
\text { mortgage }\end{array}$ & Foreman joiner & Wife, son & apprentice & \begin{tabular}{|ll} 
No major \\
trauma
\end{tabular} \\
\hline $\begin{array}{l}\mathrm{P} 109 \\
8 \mathrm{M}\end{array}$ & $\begin{array}{l}\text { Owns with } \\
\text { mortgage }\end{array}$ & Bus driver & Wife & & \begin{tabular}{|l|} 
Divorce, \\
redundancy
\end{tabular} \\
\hline $\begin{array}{l}\text { P266 } \\
M\end{array}$ & $\begin{array}{l}\text { Owns with } \\
\text { mortgage }\end{array}$ & Driver & Wife, son & apprentice & Wife's illness \\
\hline
\end{tabular}


P148 identified herself as a capable and friendly woman, living with her husband and child in a house they had bought together and child in SE England. She was busy with a routine job in the financial services and reported an active social life and networks, though she belonged to no clubs. Only later on in the interview did she-apparently willingly, even cheerfully-disclose a traumatic life. Pregnant at age 16, she was forced by her mother to marry the baby's father who she did not love. She plucked up courage to leave him and her young son when she was 18 or 19. She moved back into her father's home and then to a bedsit. In her mid-twenties, she fell in love with a different man, but after her new son was born, her husband becomes more distant. He began drinking heavily and started a secret affair with her best friend, and subsequently began to physically attack her. Following several years of serious physical abuse, she left him after an epiphany when she realised that her son had been so desensitised to violence that he carried on drawing whilst she was being attacked. She moved back to her mother's house.

This account can be articulated in terms of a narrative of subjectification in which P148 presented a life story of moving from a state of powerlessness, followed by epiphany leading to a sense of reclaiming agency. Early on in her account, she talks about how she moved to her current flat:

Prior to that I was with my daughter's father, my ex-husband, and we lived \{PLACE2, London\} area, we shared a flat which was his flat. It was somewhere that I never felt that was my own and then when we divorced he gave me the deposit on the flat that I bought in $\{$ STREET1\}, that was kind of our settlement between the two of us, and I was there in \{STREET1\} eight years before I decided I was going to move.

This paragraph presents a characteristic structure in which P148 presents herself as passive before going onto recover agency. This call and response structure, of being in a passive position before recovering a sense of agency, is a constant feature of P148's account as she narrates her life history.

Pregnant at 16, had a baby when I was 17, I wasn't married. Tirty-three years ago that wasn't the sort of thing that you often heard about and things were very, very strict... Dad come over, wasn't very happy, he was with his new partner, both agreed that I should have an abortion. I was 16 and a 16 year old 33 years ago didn't have a lot of say or opinions about anything, and my mum said I had to keep the baby.

This account of having no choice is then flipped into an account of choice:

my first husband, I wasn't even sure--, I don't even think I loved him because it was just one of those things I was forced into doing. Lived with him and his parents for about two years...... Again, I could have only been about 18, 19 , and I don't exactly know what it was that made me decide to leave \{EXHUSBAND1\} on this particular day, $\{\mathrm{SON} 1\}$ was at school--, I had no thoughts about $\{\mathrm{SON} 1\}$, it's really dreadful, only that I knew my next door 
neighbour \{NEIGHBOUR1, female\} would pick him up from school as she always did.

As was the case with several female respondents, meeting a loving partner after a history of abusive relationships is seen as a defining moment in allowing her to move on with her life. For SO148, "there was something between us" when she met her current husband.

P285 is less traumatic but also relates this structure of epiphany as a means of recovering agency and meaning:

Probably thought--, I've always thought really that I've had an average life, you know, with married, the "two point four kids". Got through, never had a lot of money, never--, life was never easy-easy, but we always managed. But I always thought there was more in life for me than where I was. I think you grow apart sometimes from people as you get older and that's mainly one of the reasons that my marriage split up back in 1994, not really because there was anybody else, he just had different priorities to me.... And it was a bit daft really, it had been brewing and I'm never normally ill and I'd been in bed with tonsillitis and it was--, he was that sad that he couldn't even cook a meal for the kids. He never did anything. I suppose I'd always done everything and he'd never done anything, if that makes sense, to the point that when I'm in bed he'd have to take them to a cafe to feed them. I've got up--, I've--, I've been really, really ill, the doctor had had to come out and I was struggling to cope, 'cause like I say, I'm never ill, and I'd got up that morning and he'd gone to work and I'd just come down and the house was a mess and I was just crying and I thought, no I can't do this anymore, I've had enough. And it was February time, just after Valentine's Day, and he came home and we had a big argument and that was it. And I knew at the moment that he left the house that my marriage was over, it was just a sense of relief.

....You know, and it was a shame 'cause like we'd done 20-odd years together but, you know, and frightening as well 'cause all of sudden you've got financial responsibilities, haven't you, and you've got to cope. And I went out from there and I held down about five jobs.

.... think we made the decision to end the marriage was a key turning point because knowing then that there was more out there to life, you didn't have a choice, you had to go and do it, you know, sink or swim weren't it? So that was. And then, I suppose, meeting \{current HUSBAND2\} really.

Our argument is not that we should read these personalised accounts to indicate that there are not deep structural processes at work which erode the lives of those at the most precarious ends of class relations. The kind of insecurities and vulnerabilities which these respondents report is, unfortunately, exactly what one might expect given the precarity of their situations. Rather, our point is that these respondents do-at age 50, anyway-show considerable ingenuity and creativity in finding a way of coming to terms with their traumas. We need to recognise this sense of agency if we are to better 
understand their political attitudes and capacity for challenging the status quo. Our argument is partly against certain renderings of Bourdieu who identify precarity as defined by the culture of necessity in which they have little choice. In fact, these narratives mostly articulate a sense of pride of being able to reach some kind of a state of personal reconciliation. This is not to be conflated with a sense that these respondents feel they have reached a secure social position because as we have seen, they continue to feel marginalised, but nonetheless, there is a sense of reconciliation.

Interestingly, only one respondent, P241, did not articulate this sense of recovery. He was still dealing with multiple traumas, including recovering from cancer, losing his job on the railways, marital break-up and allegations of paedophile criminality. He was the one respondent whose scores on the well-being indicators (see Table 2 above) were lower than any other respondent, and in this respect, he was the most striking outlier of the entire sample. He was very much in the grip of fear and insecurity. The observation notes read:

The interviewee was very friendly and welcoming. However, he described himself as being "depressed", and broke down in tears at one point during the interview when talking about his children. He revealed some very intimate and sensitive information about himself and his past life.... The interviewer's perception is that the interviewee is very lonely and did not want the discussion to end.

What is different about P241's account is his inability to put his difficulties in the past, but instead they continue to "haunt" (see McKenzie 2015) him:

I had the heart attack in '98, hmmm, just--, I split up with my wife in September '98, I took the heart attack in November. Hmmm, at that time I was told I wasn't expected to live. Hmmm... and they told me to make a will and everything, but I'm still here, so--

But it's--, it's always in your mind that it's going to happen again at some stage, so I don't--, I just take it day to day now. Hmmm... got everything sorted, the relevant--, I've got my will made out, I've got... letters wrote out that I need to write and things like that, so just a case, if it happens now it happens and that's it. You know. That's why I don't--, I don't go away very far, I don't--, you know.... I just live each day as it comes.

This is similar to the argument of Miles et al. (2011) regarding those NCDS respondents who are not socially mobile, that they characteristically feel that they cannot move on and that the past comes back to haunt them. But despite stereotypes of the victimised and marginalised (e.g. from the discourse of the underclass) who are supposed to exhibit this kind of hopelessness, P241 is the only interview where this attitude is displayed. Other interviews reveal a more confident persona and a sense of personal reconciliation, amounting to pride, that they have moved on with their lives. In order to understand the political propensities of the precarious, we have to take these accounts seriously, as a means of understanding why they might not feel personally alienated from the social order, even whilst recognising their disadvantages. 


\section{Conclusions}

Since its inception, sociology's core concern has focused on the "question of order", and especially how this can persist amidst major structural divides, such as class, ethnicity or gender. Why is the case that disadvantaged members of deeply unequal societies do not contest their disadvantage more than they do? Why do they often continue to commit-even if hesitantly and ambivalently-to the status quo? Differing answers to this question form the fault lines of social scientific as well as political debate. The fundamental opposition has pitched those emphasising that material and structural forces weaken the capacity of the disadvantaged to contest the rule of the powerful, against those appealing to the role of cultural, institutional and political processes in instilling dominant values into the minds of the downtrodden.

The fundamental argument of our paper is that to understand the perspectives and political engagement of the disadvantaged, we need a life course perspective which recognises the agency and capacity of those in such positions to develop a mode of reconciling themselves to their lives. This point may sound banal, but it has serious implications for current theorising which over-emphasises the misrecognition of class, or the seductive power of neoliberal capitalism, or the role of institutional forces in shaping disadvantage. We can see traces of all these factors, nonetheless, the power of individual agency even amongst those with the fewest resources and capacities still comes over. From the perspective of most respondents, it is their capacity to make a change in their lives which is central to their selfidentity-and this serves in key ways to differentiate the respondents from a wider class "collectivity".

The accounts we have discussed testify to the way that these respondents from lower class positions feel able to "own" narratives which see them as addressing vulnerable positions in their lives. To this extent, there is a certain kind of "quiet abjection" being performed in these accounts. We draw attention to the way that these narratives usually embed an account of "personal reconciliation". Here, individuals relate pragmatic strategies for reconciling themselves to traumatic events in their lives, which involves both "owning" that trauma and hence seeing abjection as stamped on their identities, yet, at the same time explicating how the respondents have managed or dealt with these concerns. This argument also helps to bring out how whilst these respondents are not formally active politically, they are highly engaged politically at a more personal and informal level.

This argument draws on the emphasis of Martin (2011) that we need to take seriously what people actually say about their lives, as they are the people most expert in understanding the position in which they are in. Such a perspective does not distract us from recognising the force of institutional, social and economic forces in constraining people's perceptions, but it allows us to see how they are marked in the lives and identities of people in their daily activities.

There are several implications for understanding the contemporary politics of class. Firstly, there is a degree of optimism in recognising that the precariat do not feel coopted into the social order. They in fact have a strong awareness of themselves as marginalised. However, it follows from the narratives I have discussed here that this group may well be attracted to individualised discourses of the "self-made" person, for they might see resonances of this in their own lives, and indeed have to a large extent 
bought into this kind of narrative. This is also a means of challenging discourses of abjection through emphasising resilience, pride and agency.

We can see this argument as a version of the "individualisation of class" argument (Savage 2000) that class divisions now operate through them being seen as marked in the lives and of individual people, and that people are much more likely to differentiate themselves from those in other classes rather than to feel a strong sense of solidarity to their "own" class. The political response, therefore, might be less to focus on collective class identities, and more to find a politics which engages with people's individual dilemmas in what we might term a "critical politics of aspiration". Wresting this kind of discourse from a liberal or conservative framing and placing it firmly into the central vision of progressive politics may be a decisive step.

\section{Abbreviations}

NCDS: National Child Development Study; UK: United Kingdom

\section{Acknowledgements}

N/A

\section{Authors' contributions}

Both authors contribute to the data analysis and writing of this paper. The authors read and approved the final manuscript.

\section{Funding}

The authors declare no founding support.

\section{Availability of data and materials}

We based our study on qualitative data from the British National Child Development Study, a cohort of Britons born in 1 week in 1958. Our paper here uses data associated with the eighth wave which was carried out between 11th August 2008 and 18th May 2009.

\section{Competing interests}

The authors declare they have no competing interests.

\section{Author details \\ ${ }^{1}$ London School of Economics and Political Science, London, UK. ${ }^{2}$ Department of Sociology, University of York, York} YO10 5DD, UK.

Received: 21 May 2020 Accepted: 22 October 2020

Published online: 21 December 2020

\section{References}

Alvaredo, F., L. Chancel, T. Piketty, E. Saez, and G. Zucman. 2017. Global inequality dynamics: New findings from WID. World. American Economic Review 107 (5): 404-409.

Atkinson, A.B. 2015. Inequality, what is to be done? Yale: Yale UP.

Atkinson, A.B., T. Piketty, and E. Saez. 2011. 'Top incomes in the long run of history. Journal of Economic Letters 49 (1): 3-71.

Beck, U., and E. Beck-Gernsheim. 2002. Individualisation: Institutionalised individualism and its social and political consequences. London: Sage.

Bourdieu, P., Accardo, A. and Emanuel, S. 1999. The weight of the world: Social suffering in contemporary society. Alhoda UK.

Calhoun, C. 1982. The question of class struggle. Oxford: Blackwells.

Calhoun, C. 2015. New forms of capitalism. London: paper given at "Successful Societies" conference January.

Charlesworth, S. 2000. The phenomenology of working class experience. Cambridge: CUP.

Derxx, P. 2013. Humanism as a meaning frame. In What is humanism and why does it matter? ed. A.B. Pinn. Durham: Acumen.

Dorling, D. 2014. Inequality and the 1 percent. London: Verso.

Elliott, J., Miles, A., Parsons, S. and Savage, M. 2010. The design and content of the "Social participation" study: A qualitative sub-study conducted as part of the age 50 (2008) sweep of the National Child Development Study.

Evans, G., 2008. Educational failure and working class white children in Britain. London Springer.

Evans, G., and J. Tilley. 2012. How parties shape class politics: Explaining the decline of the class basis of party support. British Journal of Political Science 42 (1): 137-161.

Evans, G., and Tilley, J. 2017. The new politics of class: The political exclusion of the British working class. Oxford University Press.

Flemmen, M., and Savage, M. 2017. The politics of nationalism and white racism in the UK. The British journal of sociology 68 : S233-S264.

Hills, J. 2014. Good times, bad times, the welfare myth of them and us. Bristol: Policy.

Lansey, S., and J. Mack. 2015. Breadline Britain: The rise of mass poverty. London: Oneworld.

Martin, J.-L. 2011. The explanation of social action. Chicago: Chicago UP.

McKenzie, L. 2015. Getting by. Bristol: Policy Press. 
McKibbin, R. 1998. Classes and cultures in Britain: 1918-1951. Oxford: Clarendon.

Miles, A. 2012. The social participation and identity project in Wales WISERD RESEARCH REPORTS SERIES WISERD/RRS/007.

Miles, A., M. Savage, and F. Buhlmann. 2011. Telling a modest story: Accounts of men's upward mobility from the National Child Development Study. British Journal of Sociology 62 (3): 418-441.

Offe, C., and H. Wisenthal. 1980. Two logics of collective action: Theoretical notes on social class and organizational form. Political Power and Social Theory 1: 67-115.

Pearson, H., 2016. The life project: The extraordinary story of 70,000 ordinary lives. Catapult.

Piketty, T. 2014. Capital in the 21st century. Yale: Yale UP.

Przeworski, A. 1985. Capitalism and social democracy. Cambridge: CUP.

Putnam, R. 2000. Bowling alone. New York: Simon and Schuster.

Runciman, W.G. 1966. Relative deprivation and social justice: A study of attitudes to social inequality in twentieth-century England (Vol. 13). Berkeley: University of California Press.

Savage, M. 2000. Class analysis and social transformation. Milton Keynes: Open University Press.

Savage, M., G. Bagnall, and B. Longhurst. 2001. Ordinary, ambivalent and defensive: Class identities in the north-west of England. Sociology 35 (4): 875-892.

Savage, M. 2005. Working-class identities in the 1960s: Revisiting the affluent worker study. Sociology 39(5):929-946.

Savage, M., 2010. Identities and social change in Britain since 1940: The politics of method. Oxford University Press.

Savage, M., N. Cunningham, F. Devine, S. Friedman, D. Laurison, L. Mckenzie, A. Miles, H. Snee, and P. Wakeling. 2015. Social class in the 21st century. London: Penguin.

Savage, M., Devine, F., Cunningham, N., Taylor, M., Li, Y., Hjellbrekke, J., Le Roux, B., Friedman, S., Miles A. 2013. "Social Class in the 21st Century". Sociology 47(2):219-250.

Savage, M., Silva, E., and Warde, A. 2010. "Dis-identification and class identity." in Silva, E. and Warde, A. eds., Cultural analysis and Bourdieu's legacy: Settling accounts and developing alternatives. Routledge: 60-74.

Scott, J. 1996. Stratification and power: Structures of class, status and command. Cambridge: Polity.

Shildrick, T., and R. Macdonald. 2013. Poverty talk: How people experiencing poverty deny their poverty and why they blame "the poor" Sociological Review.

Shildrick, T., R. MacDonald, and C. Webster. 2013. Poverty and insecurity: Life in "low pay, no pay" Britain. Bristol: Policy.

Skeggs, B. 1997. Formations of class and gender. London: Sage.

Skeggs, B. 2004. Class, culture, self. London: Routledge.

Standing, G. 2011. The precariat: The new dangerous class. London: Bloomsbury.

Stiglitz, J. 2011. The price of inequality. London: Penguin.

Tyler, I. 2014. Revolting subjects: Social abjection and resistance in neoliberal Britain. London: Zed.

Tyler, D.I. 2020. Stigma: The machinery of inequality. Zed Books Ltd.

Wacquant, L. 2001. Scrutinizing the street: Poverty, morality, and the pitfalls of urban ethnography. American Journal of Sociology 107 (6): 1468-1532.

White, H.C. 2008. Identity and control: How social formations emerge. 2nd ed. Princeton: Princeton University Press.

\section{Publisher's Note}

Springer Nature remains neutral with regard to jurisdictional claims in published maps and institutional affiliations.

\section{Submit your manuscript to a SpringerOpen ${ }^{\circ}$ journal and benefit from:}

- Convenient online submission

- Rigorous peer review

- Open access: articles freely available online

- High visibility within the field

- Retaining the copyright to your article

Submit your next manuscript at $\boldsymbol{s p r i n g e r o p e n . c o m ~}$ 